\title{
不同食性野生鸟类肠道微生物研究进展
}

\author{
王 娟, 高泽中, 蒋一婷, 万冬梅* \\ 辽宁大学 生命科学院, 辽宁省动物资源与疫病防治重点实验室, 沈阳 110036
}

\begin{abstract}
摘要:肠道微生物是庞大而多样的微生物群落,通过促进营养摄取、宿主防御、免疫调节等,在维持机体健康方面起着至关重要 的作用。宿主外部或内部环境的任何变化都会影响肠道微生物的组成,鸟类具有复杂的生活史和多样化的食性, 飞翔生活使它 们的生理活动面临更大的选择性压力, 导致肠道微生物菌群的变化更加复杂。近年来,随着基因测序技术的发展以及对鸟类肠 道微生物研究的日益重视, 导致了鸟类肠道微生物研究呈指数增长。但目前的研究主要以家禽为主, 野生鸟类肠道微生物报道 则相对较少。野生鸟类肠道微生物结构变化及其维持机制等的研究仍处于起步阶段,有较大的研究空间。从植食性、肉食性、 杂食性三种食性的鸟类肠道微生物组成及特点、影响因素等方面对前人的文献进行了全面梳理, 以期为野生鸟类肠道微生物研 究提供参考。总的来说, 植食性鸟类肠道微生物多样性最低, 以高丰度的变形菌门( Proteobacteria)、厚壁菌门(Firmicutes) 为主; 而杂食性鸟类肠道微生物多样性最高。遗传、生活史特征、人类活动、城市化、圈养行为等对鸟类肠道微生物的组成具有显著性 的影响。
\end{abstract}

关键词: 肠道微生物; 野生鸟类;食物组成; 影响因素

\section{Research advances in the intestinal microbes in wild birds with different feeding habits}

WANG Juan, GAO Zezhong, JIANG Yiting, WAN Dongmei *

Key Laboratory of Animal Resource and Epidemic Disease Prevention, Department of Life Sciences, Liaoning University, Shenyang 110036 , China

\begin{abstract}
The intestinal microbes are huge and diverse microbial communities, which play key roles in maintaining organism health through promoting nutrient uptake, defense, and immune regulation. However, any change in the intrinsic and extrinsic factors can affect the composition of gut microbiota, especially the food composition. The feeding habits of birds vary wildly, from fruit, seeds, foliage to carrion and capturing live animals. Bird life-history traits are diverse, such as migratory behavior, flight capacity, diet, mating systems, longevity and physiology, all of which may affect gut microbes. With the development of gene sequencing technology, and the increasing attention to intestinal microbes, intestinal bacterial diversity of birds has received some attention. However, publications are dominated by the studies of domestic poultry. The structure changes and maintenance mechanism, and the influencing factors of gut microbes in wild birds remain less studied. Here, we review current knowledge of the intestinal microbes in wild birds, to better understand the dynamics of wild bird gut microbiota, and will contribute to the future study of avian microbiology. In general, among the wild birds with different feeding habits, herbivorous birds have the lowest intestinal bacterial diversity, with high abundance of Proteobacteria and Firmicutes; and omnivorous birds have the highest intestines bacterial diversity. Genetics, life-history, human activities, urbanization, captive behaviors, etc. have significant effects on the bacterial diversity of wilds bird gut microbes.
\end{abstract}

基金项目: 国家自然科学基金项目(31872231); 辽宁省博士科研启动基金计划项目(2019-BS-107)

收稿日期:2020-04-25; 采用日期:2021-08-11

*通讯作者 Corresponding author.E-mail: wandongmei@ lnu.edu.cn 
Key Words : gut microbiota; wild birds; diet; influencing factors

肠道微生物是动物机体内最重要的“微生物器官”, 参与个体的营养吸收、代谢调节及免疫功能,在维持 生物体健康和适应性进化等方面均发挥着至关重要的作用 ${ }^{[1-3]}$ 。鸟类是生态系统重要的指示生物, 具有丰富 的物种多样性和遗传多样性。近年来, 随着分子生物学技术的发展以及对鸟类种群的日益重视, 对于乌类肠 道微生物组成及功能等的研究也呈指数增长 ${ }^{[4-5]}$ 。然而, 受到野外条件下取样困难、DNA 提取量低等因素的 限制, 研究主要以家禽的研究为主, 对于野生鸟类肠道微生物的研究报道则相对较少 ${ }^{[3,6-7]}$ 。

复杂的生活史特征、多样化的食性、交配系统、生理特征、飞翔生活、长距离迁徙等使鸟类的生理活动面临 更强的选择性压力, 使其肠道微生物菌群的变化更加复杂。鸟类肠道微生物组成及多样性受物种、环境、生活 史阶段、消化道区域等多种因素的影响 ${ }^{[1,4,7-8]}$, 特别是食物组成对鸟类肠道微生物的形成具有极其重要的作 用 ${ }^{[9]}$ 。鸟类的食性复杂, 如森林鸟类根据食性可分为食果鸟、食蜜鸟、食谷鸟、食虫鸟、食肉鸟、杂食鸟等类 群 $^{[10]}$ 。其中, 食果鸟、食谷鸟、食蜜鸟等均以植物性食物为食; 食虫鸟、食肉鸟、食腐鸟等均以肉食性食物为主 要食物来源。而海洋及湿地中的鸟类多为肉食性或杂食性饮食 ${ }^{[11]}$ 。复杂的食物组成导致鸟类肠道微生物更 加复杂多样。

为了更好的了解不同食性野生鸟类肠道微生物特点, 在本研究中, 将分别从植食性鸟类、肉食性鸟类和杂 食性鸟类的角度出发, 对前人的文献进行全面梳理, 分析不同食性的鸟类肠道微生物的组成、特点、影响因素 及鸟类肠道微生物研究方法, 以期为野生鸟类肠道微生物研究提供参考。

\section{1 野生鸟类肠道微生物与食性关系}

\section{1 植食性鸟类的肠道微生物研究现状}

目前, 关于植食性鸟类肠道微生物研究主要集中于鸮面鹦鹉 (Strigops habroptilus) ${ }^{[12]}$ 、北非橙簇花蜜鸟 (Cinnyris osea $)^{[13]}$ 、䳸雉 $(\text { Opisthocomus hoazin })^{[14]}$ 、安氏蜂鸟 $(\text { Calypte anna })^{[15]}$ 等种群。

植食性鸟类食物组成较为单一, 肠道微生物多样性相对较低, 以高丰富度的变形菌门 (Proteobacteria) 和 厚壁菌门 (Firmicutes) 为主。此外, 在以烟草花蜜为食的北非橙簇花蜜鸟 ${ }^{[13]}$ 和安氏蜂鸟 ${ }^{[15]}$ 粪便样品中均发现 了低丰度的放线菌门(Actinobacteria) 细菌。

食物组成对植食性鸟类肠道微生物菌群具有重要影响, 外源性增加北非橙簇花蜜鸟食物中尼古丁和新烟 碱等毒性物质浓度后, 其肠道微生物中尼古丁及新烟碱降解菌属的细菌丰度显著升高 ${ }^{[13]}$ 。黁雉具有与反刍 动物相似的前肠发酵结构, 其肠道内形成与食物消化作用相关的微生物群落, 前肠以拟杆菌门 (Bacteroidetes) 和螺旋体门 (Spirochaetes) 为主, 用于消化纤维素类食物, 后肠中以消化蛋白质的变形菌门( Proteobacteria) 与厚 壁菌门(Firmicutes) 为主 ${ }^{[14]}$ 。

作为新西兰特有的濒临灭绝的植食性鸟类, 鸮面鹦鹉肠道微生物组成受到广泛关注, 研究发现, 鸮面鹦鹉 肠道微生物以费格森埃希菌 (Escherichia fergusonii) 为主, 其分离株具有广泛的碳水化合物代谢基因, 能够代 谢肠道内多种营养物质; 该菌株与其他肠道微生物间几乎无关联,在不同的环境条件下,均保持鸮面鹦鹉稳定 的肠道生态系统 ${ }^{[12,16-17]}$ 。为了降低人工喂养的倠鸟的死亡率, 养护人员将冷冻的健康成年鸮面鹦鹉粪便悬浮 液喂养给圈养的雉鸟。然而, 测定发现, 冷冻减少了粪便悬浮液中 $99.86 \%$ 的菌群丰富, 采用冷冻成鸟粪便补 充雉鸟肠道微生物丰度的方法是需要进一步考虑的 ${ }^{[18]}$ 。

1.2 肉食性鸟类的肠道微生物研究现状

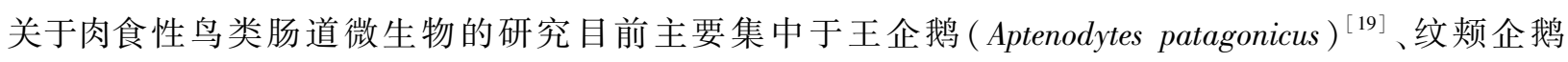
(Pygoscelis antarctica)、白眉企鹅 (Pygoscelis papua $)^{[20-21]}$ 、小企我 (Eudyptula minor)、短尾鵻 (Ardenna

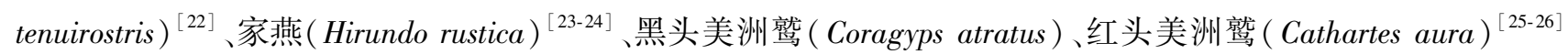
及部分水鸟 ${ }^{[27-28]}$ 。 
肉食性鸟类肠道微生物组成中优势菌集中于厚壁菌门(Firmicutes) 和变形菌门(Proteobacteria)。此外,在 黑头美洲鹑、红头美洲熟、小企鹅、王企鹅、红颈滨敄 (Calidris ruficollis) 等肉食性鸟类肠道内发现较高含量的 梭杆菌 (Fusobacteria)。

目前, 肉食性鸟类肠道微生物的研究集中在两方面内容。一是关于肠道微生物的组成与功效的研究。以 腐肉为食的黑头美洲鹑和红头美洲熟肠道微生物组成和结构异常稳定, 以梭菌 (Clostridia) 和梭杆菌 (Fusobacteria) 为主要类群, 此外, 其肠道内也发现了斯特菌抗性细菌等有益微生物基因以及噬菌体、蛭型轮 虫等基因, 体现了其肠道微生物对极端饮食的适应 ${ }^{[25-26]}$ 。与以野生猎物为食的种群相比, 采食牲畜腐肉的赤 㚜 (Milvus milvus) 种群肠道微生物中沙门氏菌 (Salmonella sp.) 感染率升高 ${ }^{[29]}$ 。家燕是重要的食虫益鸟, 在家 燕种群中, 同巢雉鸟之间、配偶对之间肠道微生物相似性较高, 且雉鸟的微生物多样性高于成鸟 ${ }^{[24]}$; 肠道微生 物组成与种群 “平均肠道微生物” 差异较大的成年个体往往具有较低的生存率 ${ }^{[23]}$; 种群水平上, 具有相似肠 道微生物组成的个体, 对植物血凝素诱导的免疫反应的相似度较高 ${ }^{[30]}$ 。

另一方面研究主要集中于生长、发育、换羽、迁徙等生活史过程对鸟类肠道微生物结构的影响 ${ }^{[7]}$ 。黑腹

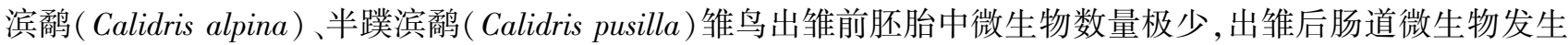
快速定植, 推断胚胎的内脏很可能没有微生物存在, 肠道微生物很可能是通过环境接种而建立的 ${ }^{[31]}$ 。短尾鸌 发育过程中, 肠道微生物群相对较稳定, 而小企鹅肠道微生物组成存在显著的波动, 厚壁菌门(Firmicutes) 和 拟杆菌门 (Bacteroidetes) 细菌丰度呈显著上升趋势, 这两种海鸟的成鸟与雉鸟间肠道微生物区系相似性均较 低 ${ }^{[22]}$ 。换羽禁食期间,王企鹅肠道微生物中梭杆菌门(Fusobacteria) 丰富度增加, 变形菌门 (Proteobacteria) 和 拟杆菌门 (Bacteroidetes) 的丰富度下降; 小企鹅肠道中厚壁菌门 (Firmicutes) 丰富度下降, 拟杆菌门 (Bacteroidetes) 丰富度增加 ${ }^{[19]}$; 白眉企鹅细菌多样性显著增加, 不同种群形成不同的细菌群落, 肠道微生物的 变化受鸟种的影响较大 ${ }^{[20]}$ 。通过细胞培养法培养隐噮 (Geronticus eremita) 微生物样本, 显示微生物的定植具 有明显的组织趋向性, 不同组织间微生物群落差异显著 ${ }^{[32]}$ 。对红颈滨敄和弯嘴滨敄 ( Calidris ferruginea) 等迁 徙水鸟的研究发现, 迁徙个体肠道内放线菌 (Actinobacteria) 丰度始终高于未迁徙个体, 特别是棒状杆菌属 (Corynebacterium) 细菌, 其在迁徙个体肠道内丰富度显著提高 ${ }^{[33]}$ 。

1.3 杂食性鸟类的肠道微生物研究现状

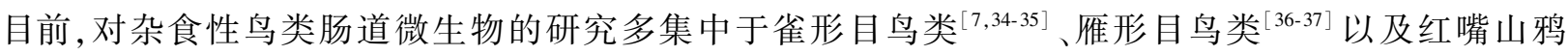
(Pyrrhocorax pyrrhocorax ${ }^{[38]}$, 翻石璚( Arenaria interpres) ${ }^{[27]}$ 等种群。

杂食性鸟类的食物组成多样, 部分种群食性随季节发生改变,其肠道微生物组成也相对复杂,以厚壁菌门 (Firmicutes)、变形菌门(Proteobacteria)、拟杆菌门(Bacteroidetes)、放线菌门(Actinobacteria) 细菌为主 ${ }^{[7]}$ 。在大

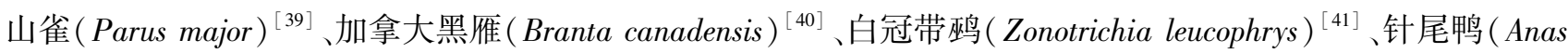
acuta)、绿眉鸭 (A. americana)、琵嘴鸭 (A. clypeata)、绿头鸭 (A. platyrhynchos $)^{[42]}$ 等的肠道内发现了丰富度大 于 $1 \%$ 的软壁菌门(Tenericutes)。在斑头雁 (Anser indicus) $)^{[43]}$ 、白头鹤 (Grus monachac $)^{[44]}$ 、针尾鸭 ${ }^{[42]}$ 中发现了 丰富度大于 $1 \%$ 的梭杆菌门(Fusobacteria) 细菌。

杂食性鸟类肠道微生物的研究主要集中于三方面内容。首先是人类活动对鸟类肠道微生物的影响。在 加拉帕戈斯群岛达尔文雀的研究中发现, 人类活动地点内的中地雀 (Geospiza fortis) 肠道微生物多样性降低, 与小地雀 (Geospiza fuliginosa) 之间微生物多样性差异增加 ${ }^{[45]}$ 。白冠带鸥肠道微生物多样性与城市环境中的 树木覆盖度、防水能力等相关,城市环境中雄性白冠带雨肠道微生物多样性显著增加 ${ }^{[41]}$ 。而在家麻雀 (Passer domesticus) 的研究中发现, 城市化显著改变了家麻雀肠道微生物的组成, 城市环境中的家麻雀肠道内含有更 多来自变形菌门 (Proteobacteria) 的纲级和目级微生物, 这些微生物与哺乳动物肠道内多种疾病有关 ${ }^{[35]}$ 。

其次,宿主遗传、发育过程、不同肠道区域、食物组成等对鸟类肠道微生物群落结构具有显著性影响。寄 生于喜鹊 (Pica pica) 巢中的大斑风头鹃 (Clamator glandarius) 雉鸟肠道微生物结构与巢内喜鹊雉鸟显著不 同, 其肠道中含有喜鹊维鸟与大斑风头鹃亲鸟的混合微生物种群 ${ }^{[46]}$ 。寄生于其它繁殖巢的斑胸草雀 
(Taeniopygia guttata) 雉鸟肠道微生物与养父母肠道微生物群落结构相似度更高, 而人工喂养的斑胸草雀雏鸟 肠道微生物的多样性较低, 表明了鸟类双亲在塑造雉鸟肠道微生物多样性中的重要性 ${ }^{[4]}$ 。野生家麻雀雉鸟 肠道微生物组成随日龄的增加发生变化, 在雉鸟第九天左右, 肠腔内变形菌门(Proteobacteria) 的丰富度下降, 厚壁菌门 (Firmicutes) 丰富度增加 ${ }^{[48]}$ 。采用抗生素处理后, 家麻雀雉鸟的生长速度和食物转化效率提高 ${ }^{\left[{ }^{[49}\right.}$ 。 斑头雁成鸟泄殖腔微生物组成及多样性均显著高于雉鸟, 成鸟与维鸟间微生物结构显著不同 ${ }^{[50]}$ 。在加拿大 黑雁的研究中发现, 同一个体内不同肠道区域微生物区系在丰富度、组成上显著不同, 结肠内微生物丰度最 高; 不同个体间结肠微生物群落相似性最高, 反映了消化道下游微生物群落的物理混合, 这也是肠道内不同微 生物家族共存的主要原因之一 ${ }^{[40]}$ 。长江中下游流域越冬的白额雁(Anser albifrons)、豆雁(Anser fabalis)、鸿雁 (Anser cygnoides) 的肠道微生物多样性、群落结构、微生物分子生态网络的结构等均存在显著差异,但不同个 体肠道微生物中均存在大量参与物质和能量代谢的基因 ${ }^{[51]}$ 。

此外,一些驯化鸟类的肠道微生物正在得到越来越多的关注 ${ }^{[52]}$ 。野生西方松鸡 (Tetrao urogallus) 肠道微 生物以互养菌门(Synergistetes)、放线菌门(Actinobacteria) 及梭菌目 (Clostridiales) 为主, 但圈养的个体以 $\gamma$-变 形菌纲 (Gammaproteobacteria) 细菌为主。人工饲养的斑头雁肠道微生物中拟杆菌门(Bacteroidetes) 丰富度增 加, 肠道内与碳水化合物转运和代谢、能量代谢、辅酶转运等功能相关的微生物基因浓度显著升高 ${ }^{[43]}$ 。鸿雁 是一种重要的经济型鸟类, 与野生种群相比, 养殖鸿雁肠道微生物中梭菌 (Clostridium) 丰富度降低,SMB53、肠 球菌 (Enterococcus)、类芽狍杆菌 (Paenibacillus) 丰富度升高 ${ }^{[53]}$; 其血液宏基因组和肠道宏基因组在糖酵解/糖 异生、丙酸代谢、柠檬酸循环、淀粉和蔗糖代谢等功能基因上存在广泛的富集共享 ${ }^{[3]}$ 。

\section{2 研究方法}

野外条件下样品获取困难是导致野生鸟类肠道微生物研究较少的主要原因之一 ${ }^{[6]}$ 。鸟类肠道微生物样 品获取方法包括致死性采样和非致死性采样两种。致死性采样是指通过解剖, 获取鸟类不同肠道组织内容 物,测定其微生物的组成。该方法可以准确反映鸟类不同肠道区域微生物的组成。但基于对鸟类种群保护的 策略,致死性采样仅用于实验室条件下样本的获取。如在鹤㕫 (Coturnix japonica) 的研究中, 通过解剖获得肠 道内容物, 分析其肠道微生物组成, 并探究肠道微生物组成与宿主压力应激反应间的关系 ${ }^{\left[{ }^{[4]}\right.}$ 。

泄殖腔拭子、粪便等非致死性样本是目前鸟类肠道微生物研究的主要样本来源 ${ }^{[1,4,7,9]}$ 。如 Corl 等 ${ }^{[55]}$ 采 用无菌拭子采集获得仓鸮 (Tyto alba) 泄殖腔内微生物样本。Teyssier 等采用无菌磷酸盐缓冲液冲洗获得家麻 雀泄殖腔微生物样本 ${ }^{[8]}$ 。 $\mathrm{Fu}$ 等直接在白头鹤活动地收集新鲜粪便, 分析其肠道微生物组成 ${ }^{[56]}$ 。非致死性样 本获取方法简单, 对鸟类个体伤害较小, 目前被越来越多的用于野生鸟类肠道微生物研究。但粪便、泄殖腔拭 子只能反映鸟类大肠内微生物组成, 对个体不同肠道区域微生物组成的反映较差 ${ }^{[9]}$ 。

野外条件下,样本的保存同样是限制鸟类肠道微生物研究的重要因素。为了更准确的反映鸟类肠道微生 物的组成, 研究者通常采用 $-80^{\circ} \mathrm{C}$ 液氮或 $-20^{\circ} \mathrm{C}$ 冰箱保存鸟类粪便或泄殖腔拭子样本 ${ }^{[7,55]}$ 。但液氮或冰箱储 存条件增加了野外条件下的工作难度。近年来, 乙醇保存的方法逐渐兴起, Bodawatta 等通过实验证明, 乙醇 保存样本中细菌群落组成与新鲜样品无显著性差异, 证明该方法确实可行 ${ }^{[57]}$ 。

此外,基因组 DNA 的提取和扩增是进行肠道微生物测定的前提。对于小型鸟类,粪便样品体积较小, DNA 的提取量较低,提高 PCR 准确度及深度对于提高测序精确度具有重要意义。Davidson 等采用滤纸片吸 附大山雀新鲜粪便样本中的尿液,降低尿素对 DNA 扩增的抑制作用,增加基因扩增深度 ${ }^{[58]}$; Luis Víquez-R 等 采用 PNA-DNA 夹方法, 抑制加岛嘲鸫 (Mimus parvulus) 线粒体 DNA 或饮食中叶绿体 DNA 的 PCR 扩增, 增加 样品扩增序列的精确度 ${ }^{[59]}$ 。

$16 \mathrm{~S}$ rRNA 基因测序技术是目前常用的肠道微生物多样性分析方法 ${ }^{[5,7]}$ 。该方法测定准确度较高, 成本相 对较低,被广泛应用于鸟类肠道微生物研究 ${ }^{[3,49,53]}$ 。宏基因组测序技术通过对样品中的全基因组 DNA 进行 高通量测序,分析样本中微生物的群落结构、基因功能、代谢网络等信息。目前,该技术也被应用于鸟类肠道 
微生物分析。如 Wang 等通过宏基因组测序技术, 分析野生及人工养殖的斑头雁肠道微生物群落结构及基因 功能 ${ }^{[43]}$ 。肠道微生物的培养同样是分析鸟类肠道微生物组成的重要手段, Lobato 等以无菌拭子收集非洲圣 多美岛的绿棕鸫 (Turdus olivaceofuscus) 及相邻加蓬大陆的非洲鸫 (Turdus olivaceofuscus) 泄殖腔内微生物样本, 采用不同培养基培养后,发现两者在细菌组成上差异较大,鉴别的 14 个细菌类群中,仅 5 种共享,且绿棕鸫种 群具有更高丰度的格兰仕阴性细菌 ${ }^{[00]}$ 。

\section{3 总结与展望}

近年来,随着基因测序技术的发展及肠道微生物研究方法的逐渐完善,野生鸟类肠道微生物相关研究显 著增加, 人们对野生鸟类肠道微生物的组成、结构特征及影响因素有了一定的了解, 但目前的研究结果多为描 述性研究,缺乏深人作用机制探究。

作为机体内最庞大、最复杂的微生态系统,肠道微生物与动物代谢、免疫防御等息息相关。Hologenome 理论认为, 微生物群落与其宿主生物体一起进化,在环境胁迫时,有助于提高宿主的生存、表型可塑性和生殖 性能等适应参数。鸟类复杂的生活史、食性、婚配体制、飞翔生活等使其面临较强的选择性压力,在这些压力 条件下,鸟类肠道微生物会发生怎样的调整? 其调整的策略及生理机制又是怎样? 在面临全球气候变暖的大 背景下,野生鸟类肠道微生物又会发生怎样的变化,以提高个体的适应能力? 这些变化对宿主的生存又产生 怎样的影响? 这都需要人们深人探究。

\section{参考文献 (References) :}

[ 1 ] Li Y P, Yang H M, Xu L, Wang Z Y, Zhao Y, Chen X S. Effects of dietary fiber levels on cecal microbiota composition in geese. AsianAustralasian Journal of Animal Sciences, 2018, 31(8): 1285-1290.

[ 2 ] Hooper L V, Littman D R, Macpherson A J. Interactions between the microbiota and the immune system. Science, 2012, 336(6086): $1268-1273$.

[ 3 ] Gao G L, Zhao X Z, Li Q, He C, Zhao W J, Liu S Y, Ding J M, Ye W X, Wang J, Chen Y, Wang H W, Li J, Luo Y, Su J, Huang Y, Liu Z H, Dai R H, Shi Y X, Meng H, Wang Q G. Genome and metagenome analyses reveal adaptive evolution of the host and interaction with the gut microbiota in the goose. Scientific Reports, 2016, 6(1): 32961.

[ 4 ] Grond K, Sandercock B K, Jumpponen A, Zeglin L H. The avian gut microbiota: community, physiology and function in wild birds. Journal of Avian Biology, 2018, 49(11): e01788.

[ 5 ] Waite D W, Taylor M W. Exploring the avian gut microbiota: current trends and future directions. Frontiers in Microbiology, 2015 , 6: 673.

[6] 周立志. 鸟类肠道微生态学及其研究热点. 安徽大学学报: 自然科学版, 2018, 42(6): 14-21.

[ 7 ] 高泽中. 不同季节杂色山雀肠道微生物组成及与免疫关系的研究 [D]. 沈阳: 辽宁大学, 2020.

[ 8 ] Hird S M, Sánchez C, Carstens B C, Brumfield R T. Comparative gut microbiota of 59 neotropical bird species. Frontiers in Microbiology, 2015, 6: 1403

[ 9 ] Youngblut N D, Reischer G H, Walters W, Schuster N, Walzer C, Stalder G, Ley R E, Farnleitner A H. Host diet and evolutionary history explain different aspects of gut microbiome diversity among vertebrate clades. Nature Communications, 2019, 10(1): 2200.

[10］丁平, 张正旺, 梁伟, 李湘涛. 中国森林鸟类. 长沙: 湖南科学技术出版社, 2019: 12-12.

[11］马志军, 陈水华. 中国海洋与湿地鸟类. 长沙: 湖南科学技术出版社, 2018: 5-5.

[12] Perry E K, Digby A, Taylor M W. The low-diversity fecal microbiota of the critically endangered Kākāpō is robust to anthropogenic dietary and geographic influences. Frontiers in Microbiology, 2017, 8: 2033.

[13] Gunasekaran M, Lalzar M, Sharaby Y, Izhaki I, Halpern M. The effect of toxic pyridine-alkaloid secondary metabolites on the sunbird gut microbiome. npj Biofilms and Microbiomes, 2020, 6(1): 53.

[14] Godoy-Vitorino F, Goldfarb K C, Karaoz U, Leal S, Garcia-Amado M A, Hugenholtz P, Tringe S G, Brodie E L, Dominguez-Bello M G. Comparative analyses of foregut and hindgut bacterial communities in hoatzins and cows. The ISME Journal, 2012, 6(3) : 531-541.

[15] Lee C, Tell L A, Hilfer T, Vannette R L. Microbial communities in hummingbird feeders are distinct from floral nectar and influenced by bird visitation. Proceedings of the Royal Society B : Biological Sciences, 2019, 286(1898) : 20182295.

[16] Waite D W, Dsouza M, Sekiguchi Y, Hugenholtz P, Taylor M W. Network-guided genomic and metagenomic analysis of the faecal microbiota of the critically endangered kakapo. Scientific Reports, 2018, 8(1): 8128. 
[17] Waite D W, Deines P, Taylor M W. Gut microbiome of the critically endangered new Zealand parrot, the kakapo (Strigops habroptilus). PLoS One, 2012, 7(4): e35803.

[18] Waite D W, Deines P, Taylor M W. Quantifying the impact of storage procedures for faecal bacteriotherapy in the critically endangered New Zealand Parrot, the Kakapo (Strigops habroptilus). Zoo Biology, 2013, 32(6) : 620-625.

[19] Dewar M L, Arnould J P Y, Krause L, Trathan P, Dann P, Smith S C. Influence of fasting during moult on the faecal microbiota of penguins. PLoS One, 2014, 9(6): e99996.

[20] Lee W Y, Cho H, Kim M, Tripathi B M, Jung J W, Chung H, Kim J H. Faecal microbiota changes associated with the moult fast in chinstrap and Gentoo penguins. PLoS One, 2019, 14(5): e0216565.

[21] Yew W C, Pearce D A, Dunn M J, Adlard S, Alias S A, Samah A A, Convey P. Links between bacteria derived from penguin guts and deposited guano and the surrounding soil microbiota. Polar Biology, 2018, 41(2): 269-281.

[22] Dewar M L, Arnould J P Y, Allnutt T R, Crowley T, Krause L, Reynolds J, Dann P, Smith S C. Microbiota of little penguins and short-tailed shearwaters during development. PLoS One, 2017, 12(8) : e0183117.

[23] Ambrosini R, Corti M, Franzetti A, Caprioli M, Rubolini D, Motta V M, Costanzo A, Saino N, Gandolfi I. Cloacal microbiomes and ecology of individual barn swallows. FEMS Microbiology Ecology, 2019, 95(6) : fiz061.

[24] Kreisinger J, Kropáčková L, Petrželková A, Adámková M, Tomášek O, Martin J F, Michálková R, Albrecht T. Temporal stability and the effect of transgenerational transfer on fecal microbiota structure in a long distance migratory bird. Frontiers in Microbiology, $2017,8: 50$.

[25] Mendoza M L Z, Roggenbuck M, Vargas K M, Hansen L H, Brunak S, Gilbert M T P, Sicheritz-Pontén T. Protective role of the vulture facial skin and gut microbiomes aid adaptation to scavenging. Acta Veterinaria Scandinavica, 2018, 60(1): 61.

[26] Roggenbuck M, Schnell I B, Blom N, Bælum J, Bertelsen M F, Sicheritz-Pontén T, Sørensen S J, Gilbert M T P, Graves G R, Hansen L H. The microbiome of new world vultures. Nature Communications, 2014, 5(1) : 5498.

[27] Grond K, Ryu H, Baker A J, Domingo J W S, Buehler D M. Gastro-intestinal microbiota of two migratory shorebird species during spring migration staging in Delaware Bay, USA. Journal of Ornithology, 2014, 155(4) : 969-977.

[28] Dewar M L, Arnould J P Y, Krause L, Dann P, Smith S C. Interspecific variations in the faecal microbiota of Procellariiform seabirds. FEMS Microbiology Ecology, 2014, 89(1): 47-55.

[29] Blanco G. Influence of diet on the gastrointestinal flora of wintering red kites. European Journal of Wildlife Research, 2014 , 60 (4) : 695-698.

[30] Kreisinger J, Schmiedová L, Petrželková A, Tomášek O, Adámková M, Michálková R, Martin J F, Albrecht T. Fecal microbiota associated with phytohaemagglutinin-induced immune response in nestlings of a passerine bird. Ecology and Evolution, 2018, 8( 19) : 9793-9802.

[31] Grond K, Lanctot R B, Jumpponen A, Sandercock B K. Recruitment and establishment of the gut microbiome in arctic shorebirds. FEMS Microbiology Ecology, 2017, 93(12): fix142.

[32] Spergser J, Loncaric I, Tichy A, Fritz J, Scope A. The cultivable autochthonous microbiota of the critically endangered Northern bald ibis (Geronticus eremita). PLoS One, 2018, 13(4): e0195255.

[33] Risely A, Waite D W, Ujvari B, Hoye B J, Klaassen M. Active migration is associated with specific and consistent changes to gut microbiota in Calidris shorebirds. Journal of Animal Ecology, 2018, 87(2) : 428-437.

[34] Bodawatta K H, Sam K, Jønsson K A, Poulsen M. Comparative analyses of the digestive tract microbiota of new Guinean passerine birds. Frontiers in Microbiology, 2018, 9: 1830.

[35] Gadau A, Crawford M S, Mayek R, Giraudeau M, McGraw K J, Whisner C M, Kondrat-Smith C, Sweazea K L. A comparison of the nutritional physiology and gut microbiome of urban and rural house sparrows (Passer domesticus). Comparative Biochemistry and Physiology Part B: Biochemistry and Molecular Biology, 2019, 237: 110332.

[36] Wang W, Liu Y B, Yang Y S, Wang A Z, Sharshov K, Li Y, Cao M Y, Mao P Z, Li L X. Comparative analyses of the gut microbiota among three different wild geese species in the genus Anser. Journal of Basic Microbiology, 2018, 58(6) : 543-553.

[37] Xiang X J, Zhang F L, Fu R, Yan S F, Zhou L Z. Significant differences in bacterial and potentially pathogenic communities between sympatric hooded crane and greater white-fronted goose. Frontiers in Microbiology, 2019, 10: 163.

[38] Wang W, Wang A Z, Yang Y S, Wang F, Liu Y B, Zhang Y H, Sharshov K, Gui L S. Composition, diversity and function of gastrointestinal microbiota in wild red-billed choughs (Pyrrhocorax pyrrhocorax). International Microbiology, 2019, 22(4): 491-500.

[39] Kropáčková L, Pechmanová H, Vinkler M, Svobodová J, Velová H, Těšičký M, Martin J F, Kreisinger J. Variation between the oral and faecal microbiota in a free-living passerine bird, the great tit (Parus major). PLoS One, 2017, 12(6) : e0179945.

[40] Drovetski S V, O'Mahoney M, Ransome E J, Matterson K O, Lim H C, Chesser R T, Graves G R. Spatial organization of the gastrointestinal microbiota in urban Canada geese. Scientific Reports, 2018, 8(1): 3713.

[41] Phillips J N, Berlow M, Derryberry E P. The effects of landscape urbanization on the gut microbiome: an exploration into the gut of urban and rural 
white-crowned sparrows. Frontiers in Ecology and Evolution, 2018, 6: 148.

[42] Hird S M, Ganz H, Eisen J A, Boyce W M. The cloacal microbiome of five wild duck species varies by species and influenza a virus infection status. mSphere, 2018, 3(5): e00382-18.

[43] Wang W, Zheng S S, Sharshov K, Sun H, Yang F, Wang X L, Li L X, Xiao Z X. Metagenomic profiling of gut microbial communities in both wild and artificially reared Bar-headed goose (Anser indicus). MicrobiologyOpen, 2017, 6(2) : e00429.

[44] Zhao G H, Zhou L Z, Dong Y Q, Cheng Y Y, Song Y W. The gut microbiome of hooded cranes (Grus monacha) wintering at Shengjin Lake, China. MicrobiologyOpen, 2017, 6(3): e00447.

[45] Knutie S A, Chaves J A, Gotanda K M. Human activity can influence the Gut microbiota of Darwin's finches in the Galapagos Islands. Molecular Ecology, 2019, 28(9): 2441-2450.

[46] Ruiz-Rodríguez M, Martín-Vivaldi M, Martínez-Bueno M, Soler J J. Gut microbiota of great spotted cuckoo nestlings is a mixture of those of their foster magpie siblings and of cuckoo adults. Genes, 2018, 9(8):381.

[47] Chen C Y, Chen C K, Chen Y Y, Fang A, Shaw G T W, Hung C M, Wang D. Maternal gut microbes shape the early-life assembly of gut microbiota in passerine chicks via nests. Microbiome, 2020, 8(1): 129.

[48] Kohl K D, Brun A, Caviedes-Vidal E, Karasov W H. Age-related changes in the gut microbiota of wild house sparrow nestlings. IBIS, 2019, 161 (1) : 184-191.

[49] Kohl K D, Brun A, Bordenstein S R, Caviedes-Vidal E, Karasov W H. Gut microbes limit growth in house sparrow nestlings ( Passer domesticus) but not through limitations in digestive capacity. Integrative Zoology, 2018, 13(2) : 139-151.

[50] 郑思思, 王稳, 王爱真, 孙浩, 杨芳, 王雪莲, 李来兴. 斑头雁成鸟与雉鸟泄殖腔微生物的对比分析. 动物学杂志, 2018, 53 ( 4) : 641-651.

[51] Yang Y Z, Deng Y, Cao L. Characterising the interspecific variations and convergence of gut microbiota in Anseriformes herbivores at wintering areas. Scientific Reports, 2016, 6(1): 32655.

[52] Wienemann T, Schmitt-Wagner D, Meuser K, Segelbacher G, Schink B, Brune A, Berthold P. The bacterial microbiota in the ceca of Capercaillie ( Tetrao urogallus) differs between wild and captive birds. Systematic and Applied Microbiology, 2011, 34(7) : 542-551.

[53] Wang W, Zheng S S, Sharshov K, Cao J, Sun H, Yang F, Wang X L, Li L X. Distinctive gut microbial community structure in both the wild and farmed Swan goose (Anser cygnoides). Journal of Basic Microbiology, 2016, 56(11) : 1299-1307.

[54] Lyte J M, Keane J, Eckenberger J, Anthony N, Shrestha S, Marasini D, Daniels K M, Caputi V, Donoghue A M, Lyte M. Japanese quail (Coturnix japonica) as a novel model to study the relationship between the avian microbiome and microbial endocrinology-based host-microbe interactions. Microbiome, 2021, 9(1): 38 .

[55] Corl A, Charter M, Rozman G, Toledo S, Turjeman S, Kamath P L, Getz W M, Nathan R, Bowie R C K. Movement ecology and sex are linked to barn owl microbial community composition. Molecular Ecology, 2020, 29(7) : 1358-1371.

[56] Fu R, Xiang X J, Dong Y Q, Cheng L, Zhou L Z. Comparing the intestinal bacterial communies of sympatric wintering Hooded Crane ( Grus monacha) and Domestic Goose (Anser anser domesticus). Avian Research, 2020, 11(1) : 13.

[57] Bodawatta K H, Puzejova K, Sam K, Poulsen M, Jønsson K A. Cloacal swabs and alcohol bird specimens are good proxies for compositional analyses of gut microbial communities of great tits (Parus major). Animal Microbiome, 2020, 2(1) : 9.

[58] Davidson G L, Wiley N, Cooke A C, Johnson C N, Fouhy F, Reichert M S, De La Hera I, Crane J M S, Kulahci I G, Ross R P, Stanton C, Quinn J L. Diet induces parallel changes to the gut microbiota and problem solving performance in a wild bird. Scientific Reports, 2020, 10 (1) : 20783 .

[59] Víquez-R L, Fleischer R, Wilhelm K, Tschapka M, Sommer S. Jumping the green wall: the use of PNA-DNA clamps to enhance microbiome sampling depth in wildlife microbiome research. Ecology and Evolution, 2020, 10(20) : 11779-11786.

[60] Lobato E, Geraldes M, Melo M, Doutrelant C, Covas R. Diversity and composition of cultivable gut bacteria in an endemic island bird and its mainland sister species. Symbiosis, 2017, 71(2): 155-164. 